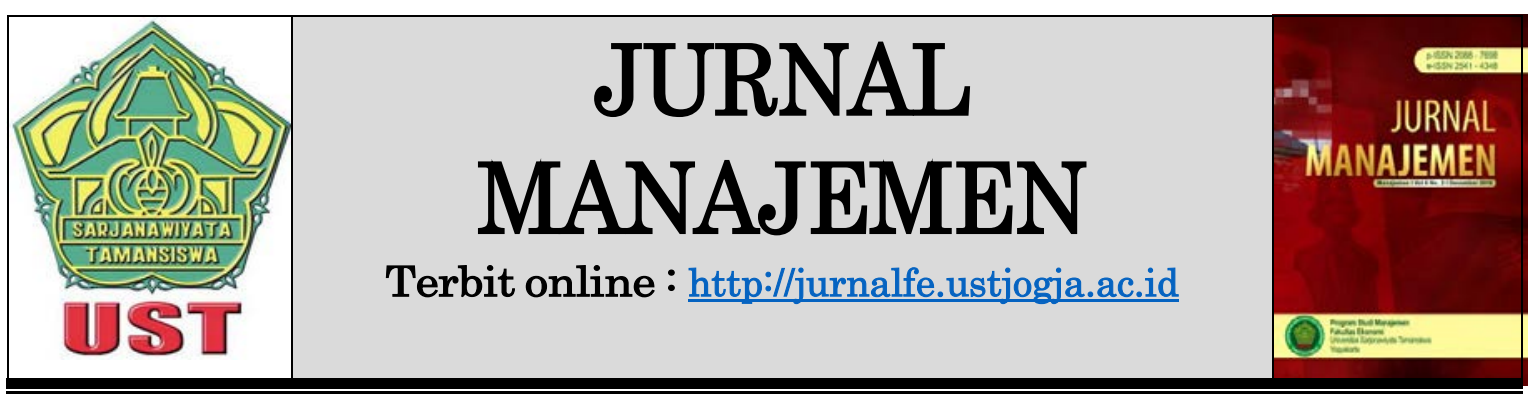

\title{
KOMUNIKASI SEBAGAI INTERVENING VARIABEL PENGARUH KARAKTERISTIK INDIVIDU TERHADAP KINERJA PEGAWAI
}

\author{
Sudung Simatupang \\ STIE Sultan Agung
}

Korespondensi: Selitaefraim@gmail.com

\begin{tabular}{ll}
\hline Informasi Naskah & Abstrak \\
\hline Diterima: & The purpose of this study is to determine \\
12 Mei & communication as an intervening variable influence \\
Revisi: & individual characteristics on employee performance. \\
25 Mei & Sample used by all civil servants (PNS) at UPT SDA \\
Terbit: & Bah Bolon, Dinas Sumber Daya Air, Cipta Karya, dan \\
28 Juni & Tata Ruang Provinsi Sumatera Utara which numbered \\
\hline Kata Kunci: & 96 employees. The analysis technique used is simple \\
Communication, & regression and multiple regression. \\
Individual & The results of the study found results: (1). There \\
Characteristics, & was a significant effect of individual character on \\
Employee & communication: (2). There is a significant effect of \\
Performance & individual character and communication on \\
& performance: (3). The results of intervening path \\
& analysis shows that individual characters can have a \\
& direct effect on employee performance and can also \\
& indirectly effect from individual character to \\
& communication (as intervening) and then towards \\
& employee performance. The results of the above \\
& analysis show that indirectly the individual character \\
& through communication has a significant influence on \\
& performance
\end{tabular}

\section{PENDAHULUAN}

Sumber daya manusia merupakan salah satu faktor yang sangat penting bahkan tidak dapat dilepaskan dari sebuah organisasi, baik institusi maupun perusahaan. Sumber daya manusia juga merupakan kunci yang menentukan perkembangan organisasi, baik instansi maupun perusahaan. Sumber daya manusia yang baik merupakan salah satu aset organisasi atau perusahaan yang harus dijaga dan dikelola dengan baik untuk membantu tercapainya tujuan organisasi. 
Kinerja pegawai menjadi hal sangat penting diperhatikan oleh setiap organisasi, karena kinerja pegawai dengan segala aspek yang ada didalamnya akan memberikan dampak secara keseluruhan bagi perkembangan organisasi. Menurut Peraturan Pemerintah Republik Indonesia Nomor 46 Tahun 2011 Tentang Penilaian Prestasi Kerja Pegawai Negeri Sipil, adapun yang menjadi dimensi penilaian kinerja pegawai yaitu sasaran kerja pegawai dan perilaku kerja.

Kinerja pegawai pada UPT SDA Bah Bolon, Dinas Sumber Daya Air, Cipta Karya, dan Tata Ruang Provinsi Sumatera Utara Jl. Asahan Km. 3,5 Pematangsiantar masih belum optimal tentang fenomena kinerja pegawai dan data pegawai. Pada dimensi sasaran kerja pegawai (SKP) dimana hasil kerja pegawai masih banyak mendapat keluhan dari beberapa masyarakat karena pegawai kurang teliti dalam melakukan pengawasan dan pemeliharaan jaringan irigasi. Begitu juga pada dimensi perilaku kerja (PK) menunjukkan bahwa sikap pegawai yang kurang disiplin dimana masih ada beberapa pegawai yang tidak berada di kantor saat jam kerja.

Salah satu faktor yang mempengaruhi kinerja pegawai adalah komunikasi. Menurut Purwanto (2011), hubungan komunikasi yang baik adalah salah satu kunci keberhasilan organisasi, untuk meningkatkan kinerja pegawai secara keseluruhan diperlukan terjalinnya komunikasi yang baik antar unit yang ada di dalam organisasi. Salah satu faktor yang mempengaruhi kinerja pegawai adalah komunikasi. Hal ini sejalan dengan penelitian (Ardiansyah: 2016, Setyowati: 2016, Mariani dan Sariyathi :2017) bahwa komunikasi memiliki pengaruh positif dan siginifikan terhadap kinerja. Selanjutnya pendapat Robbins dan Mary (2010), arah aliran komunikasi terdiri dari 4 (empat) yaitu:1). Komunikasi ke bawah, 2).Komunikasi ke atas, 3).Komunikasi ke samping, 4).Komunikasi diagonal.

Yang menjadi fenomena yang terjadi tentang komunikasi yaitu pada komunikasi dari bawah ke atas masih belum optimal, dilihat pada beberapa pegawai menyampaikan informasi yang baik-baik saja sedangkan informasi yang berkesan negatif dihindari untuk mendapatkan zona aman. Begitu juga pada komunikasi horizontal sering terjadi kesalahpahaman antar sesama pegawai disebabkan cara penyampaian informasi yang kurang jelas.

Selain komunikasi faktor lain yang dapat mempengaruhi kinerja pegawai adalah karakteristik individu. Menurut Rahman (2013), karakteristik individu adalah ciri khas yang menunjukkan perbedaan seseorang tentang motivasi, inisiatif, kemampuan untuk tetap tegar menghadapi tugas sampai tuntas atau memecahkan masalah atau bagaimana menyesuaikan perubahan yang terkait erat dengan lingkungan yang mempengaruhi kinerja individu.Hal ini sejalan dengan penelitian terdahulu dari (Handayati :2016, Gaffar :2017, Jacobis , Kojo dan Wenas : 2015) bahwa Karakteristik individu berpengaruh positif dan signifikan terhadap kinerja karyawan.

Dimensi karakteristik individu meliputi tingkat persetujuan, tingkat keseriusan dan kesadaran, tingkat emosi yang negatif, tingkat keleluasaan dan kenyamanan dan tingkat keterbukaan. Fenomena karakteristik individu masih belum optimal dapat dilihat dari sikap pegawai yang kurang dalam bekerja sama untuk mengerjakan tugas dan tanggung jawab dan masih adanya pegawai yang kurang serius atau fokus melakukan pekerjaan sehingga 
menimbulkan hasil kerja yang tidak maksimal.

Untuk itu, penelitian ini menguji tentang karakter individu dapat berpengaruh langsung ke kinerja pegawai, pengaruh karakter individu dan komunikasi terhadap kinerja dan pengaruh karakter individu melalui komunikasi terhadap kinerja.

\section{KAJIAN PUSTAKA DAN HIPOTESIS}

Pendapat Mangkunegara (2017), "komunikasi adalah proses pemindahan informasi, ide, pengertian, dari seseorang kepada orang lain dengan harapan orang lain tersebut dapat menginterprestasikan sesuai dengan tujuan yang dimaksud" Selanjutnya pendapat Robbins dan Mary (2010), arah aliran komunikasi terdiri dari 4 (empat) yaitu: 1).Komunikasi ke bawah,.2).Komunikasi ke atas,.3).Komunikasi ke samping,.4).Komunikasi diagonal.

Huriyati, (2011) yang memberikan pengertian tentang karakteristik individu sebagai berikut:"Suatu proses psikologi yang mempengaruhi individu dalam memperoleh, mengkonsumsi serta menerima barang dan jasa serta pengalaman. Karakteristik individu merupakan faktor internal (interpersonal) yang menggerakan dan mempengaruhi perilaku individu". Griffin dalam Sule dan Kurniawan (2009), menyatakan "Model Lima Dimensi mengenai kepribadian (the Big Five Model of Personality) yaitu sebagai berikut:1). Tingkat Persetujuan (Anggreeableness), 2).Tingkat Keseriusan dan Kesadaran (Conscienctiousness), 3).Tingkat Emosi yang Negatif (Negative Emotionally), 4).Tingkat Keleluasaan dan Kenyamanan (Estraversion),. 5). Tingkat Keterbukaan (Openness),

Menurut Wirawan (2014), "kinerja merupakan salah satu variabel dependen yang berhubungan langsung dengan kepemimpinan atau melalui variabel antara atau mediasi”. Kinerja pegawai negeri sipil atau aparatur sipil negara diatur oleh Peraturan Pemerintah Republik Indonesia Nomor 46 tahun 2011 Tentang Penilaian Prestasi Kerja Pegawai Negeri Sipil. Penilaian prestasi kerja PNS merupakan suatu proses penilaian secara sistematis yang dilakukan pejabat penilai terhadap sasaran kerja pegawai dan perilaku kerja pegawai negeri sipil (PNS), (Pasal 1 ayat 2 Peraturan Pemerintah Nomor 46 tahun 2011). Tujuannya adalah untuk mengevaluasi kinerja pegawai negeri sipil (PNS), yang dapat memberi petunjuk bagi manajemen dalam rangka mengevaluasi kinerja unit dan kinerja organisasi secara keseluruhan.

Penilaian prestasi kerja pegawai negeri sipil (PNS) menggabungkan antara penilaian Sasaran Kerja Pegawai Negeri Sipil dengan Penilaian Perilaku Kerja. Penilaian prestasi kerja tersebut terdiri dari dua unsur yaitu SKP (sasaran kerja pegawai) yang terdiri dari: 1). Kuantitas merupakan ukuran jumlah atau atau banyaknya hasil kerja yang dicapai oleh seseorang pegawai.2).Kualitas merupakan ukuran mutu setiap hasil kerja yang dicapai oleh seseorang pegawai.3).Waktu merupakan ukuran lamanya proses setiap hasil kerja yang dicapai oleh seseorang pegawai.4). Biaya merupakan besaran jumlah anggaran yang digunakan setiap hasil kerja oleh seseorang pegawai dan PK (perilaku kerja) yang terdiri dari : 1). Orientasi pelayanan, 2). Integritas, 3). Komitmen, 4). Disiplin, 5). Kerjasama 6). Kepemimpinan, dengan bobot penilaian masing-masing unsur Sasaran Kerja Pegawai sebesar $60 \%$ dan 
Perilaku Kerja sebesar 40\%. Hasil penilaian prestasi kerja pegawai negeri sipil

(PNS) dimanfaatkan sebagai dasar pertimbangan.

Hipotesis dalam penelitian ini yaitu

H1 : Karakter individu dapat berpengaruh langsung ke kinerja pegawai

H2 : Karakter individu dan komunikasi berpengaruh terhadap kinerja

H3 : Karakter individu melalui komunikasi berpengaruh terhadap kinerja

Yang menjadi kerangka pemikirian dalam penelitian ini adalah:

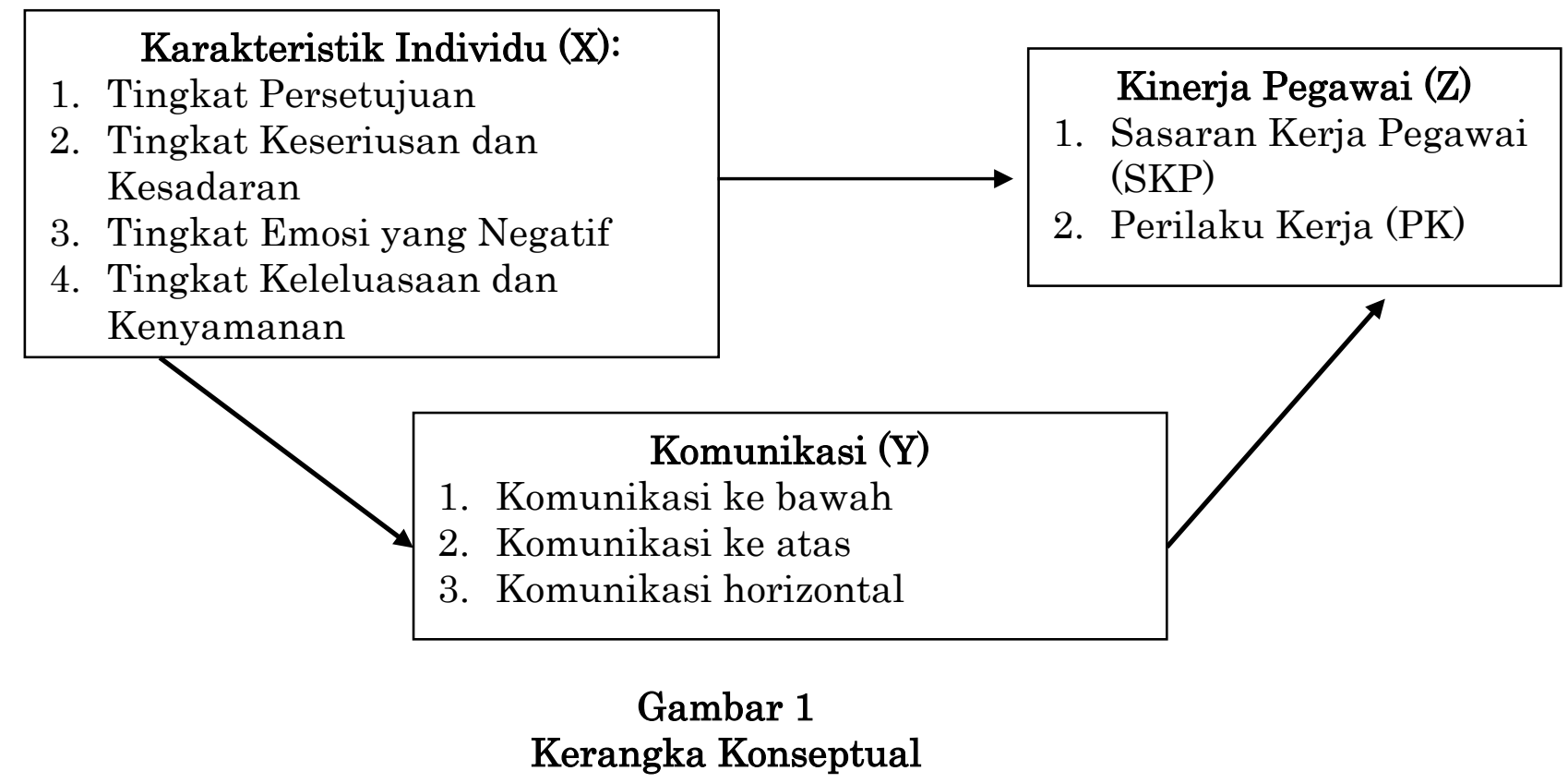

\section{METODE PENELITIAN}

Menurut Sugiyono (2016), "Populasi adalah wilayah generalisasi terdiri atas obyek/subyek yang mempunyai kualitas dan karakteristik tertentu. ditetapkan oleh peneliti untuk dipelajari dan kemudian ditarik kesimpulan" Populasi penelitian seluruh pegawai negeri sipil (PNS) pada UPT SDA Bah Bolon, Dinas Sumber Daya Air, Cipta Karya, dan Tata Ruang Provinsi Sumatera Utara Jl. Asahan Km. 3,5 Pematangsiantar yang berjumlah 96 orang pegawai dan seluruhnya dijadikan sebagai sampel. Menurut Arikunto (2013) "Penentuan pengambilan Sampel sebagai berikut: Apabila kurang dari 100 lebih baik diambil semua hingga penelitiannya merupakan penelitian populasi. Jika jumlah subjeknya besar dapat diambil antara $10-15 \%$ atau $20-55 \%$ atau lebih.

Dalam ruang lingkup penelitian ini membahas mengenai, karakteristik individu, komunikasi dan kinerja pegawai pada UPT SDA Bah Bolon, Dinas Sumber Daya Air, Cipta Karya, dan Tata Ruang Provinsi Sumatera Utara Jl. Asahan Km. 3,5 Pematangsiantar. Dimana yang menjadi dimensi karakteristik individu dapat dilihat melalui ciri-ciri biografis, kepribadian, persepsi dan sikap. Untuk dimensi komunikasi diantaranya komunikasi ke bawah, komunikasi ke atas, dan komunikasi horizontal Sedangkan dimensi kinerja 
pegawai dapat diukur melalui sasaran kerja pegawai dan perilaku kerja.

\section{HASIL DAN PEMBAHASAN}

Berdasarkan jenis kelamin bahwa untuk laki laki sebanyak 86 orang atau $90 \%$, sedangkan wanita sebanyak 10 orang atau $10 \%$ dari jumlah pengawai, usia pegawai yang paling banyak berumur 41-50 Tahun sebanyak 40 orang pegawai atau 40\%, kemudian pegawai yang berumur 51-60 tahun 36 orang atau 37\% dikuti pegawai berumur 31-40 tahun sebanyak 20 orang atau $21 \%$ dari total pegawai. Pendidikan pegawai yang paling banyak pada jenjang SMA dengan jumlah 81 orang atau 84\%, selanjutnya sarjana S-1 dengan jumlah 12 orang atau 13\% kemudian diploma sebanyak 2 orang atau $2 \%$ dan magister 1 orang atau 1\%. Untuk lama berkerja pegawai lama berkerja 11-20 tahun dengan jumlah 64 orang atau 67\%, di bawah 10 tahun 23 orang atau 24\% , lalu lama kerja 21-30 tahun 5 orang atau 5\% dan lama kerja 31-40 tahun 4 orang atau $4 \%$.

\section{Persamaan 1}

Analisis Regresi Sederhana digunakan sebagai pendekatan untuk pemodelan hubungan antara satu variabel dependen dan satu variabel independen. Dalam model regresi, variabel independen menerangkan variabel dependennya.yang dapat di lihat pada tabel berikut:

Tabel 1

Model Summary

\begin{tabular}{ccccc}
\hline Model & R & R Square & $\begin{array}{c}\text { Adjusted R } \\
\text { Square }\end{array}$ & $\begin{array}{c}\text { Std. Error of the } \\
\text { Estimate }\end{array}$ \\
\hline 1 & $.872^{\text {a }}$ & .761 & .758 & 1.812 \\
\hline
\end{tabular}

a Predictors: (Constant), Karakter_Individu(X)

Sumber : Data diolah ( 2019)

\begin{tabular}{|c|c|c|c|c|c|c|}
\hline \multicolumn{7}{|c|}{$\begin{array}{c}\text { Tabel } 2 \\
\text { Regesi Sederhana } \\
\text { Coefficients }^{\text {a }}\end{array}$} \\
\hline & \multirow{2}{*}{ Model } & \multicolumn{2}{|c|}{$\begin{array}{c}\text { Unstandardized } \\
\text { Coefficients }\end{array}$} & \multirow{2}{*}{$\begin{array}{c}\text { Standardized } \\
\text { Coefficients }\end{array}$} & \multirow{2}{*}{$\mathrm{t}$} & \multirow{2}{*}{ Sig. } \\
\hline & & B & $\begin{array}{l}\text { Std. } \\
\text { Error }\end{array}$ & & & \\
\hline \multirow[t]{2}{*}{1} & (Constant) & 2.737 & 1.882 & & 1.454 & .149 \\
\hline & $\begin{array}{l}\text { Karakter_Individu( } \\
\text { X) }\end{array}$ & .550 & .032 & .872 & 17.278 & .000 \\
\hline
\end{tabular}

a Dependent Variable: Komunikasi (Y)

Sumber : Data diolah ( 2019)

\section{Persamaan 2}

Analisis ini untuk mengetahui arah hubungan antara variabel independen dengan variabel dependen apakah masing-masing variabel independen berhubungan positif atau negatif dan untuk memprediksi nilai dari variabel 
dependen apabila nilai variabel independen mengalami kenaikan atau penurunan.

Tabel 3

Model Summary

\begin{tabular}{ccccr}
\hline Model & $\mathbf{R}$ & $\mathbf{R}$ Square & $\begin{array}{c}\text { Adjusted R } \\
\text { Square }\end{array}$ & $\begin{array}{c}\text { Std. Error of the } \\
\text { Estimate }\end{array}$ \\
\hline 1 & $.920^{\text {a }}$ & .847 & .844 & 2.767 \\
\hline a Predictors: (Constant), Komunikasi (Y), Karakter_Individu(X) \\
\multicolumn{3}{l}{ Sumber : Data diolah (2019) }
\end{tabular}

Tabel 4

Coefficients $^{a}$

\begin{tabular}{|c|c|c|c|c|c|c|}
\hline & \multirow{2}{*}{ Model } & \multicolumn{2}{|c|}{$\begin{array}{l}\text { Unstandardized } \\
\text { Coefficients }\end{array}$} & $\begin{array}{c}\text { Standardize } \\
\mathrm{d} \\
\text { Coefficients }\end{array}$ & \multirow{2}{*}{$\mathrm{t}$} & \multirow{2}{*}{ Sig. } \\
\hline & & B & $\begin{array}{l}\text { Std. } \\
\text { Error }\end{array}$ & Beta & & \\
\hline \multirow[t]{3}{*}{1} & (Constant) & 14.326 & 2.907 & & 4.928 & .000 \\
\hline & $\begin{array}{l}\text { Karakter_Individu( } \\
\text { X) }\end{array}$ & .433 & .099 & .361 & 4.358 & .000 \\
\hline & Komunikasi (Y) & 1.119 & .158 & .588 & 7.100 & .000 \\
\hline
\end{tabular}

a.Dependent Variable: Kinerja(Z)

Sumber : Data diolah ( 2019)

\section{PEMBAHASAN}

\section{Regresi Sederhana dan Berganda}

Hasil Persamaan1 dengan Regresi Sederhana tabel 2 adalah: $\mathrm{Y}=2.737$ + 0.550 (X) .Dari persamaan tersebut bermakna bahwa terdapat pengaruh positif Karakter Individu ( X) terhadap Komunikasi (Z). Selanjutnya Persamaan 2 pada tabel 4 dengan Regresi Berganda $Z=14.326+0.433(\mathrm{X})+$ 1.119 (Y) .Maka hasil dari persamaan tersebut terdapat pengaruh positif Karakter Individu ( X) terhadap Kinerja dan Komunikasi (Y) sebagai variabel intervening berpengaruh dan positif terhadap Kinerja PegawaI ( Z).

\section{Koefisen Determinasi}

Perhitungan Koefisen determinasi pada Tabel 1 menunjukan bahwa variabel Karakter Individu (X) berpengaruh terhadap Komunikasi ( Z) sebesar $\left(\mathrm{R}^{2}=0.761\right)$ berarti sisanya $24 \%$, sedangkan koefisien determinasi pada tabel 3 menunjukan bahwa Karakater Individu (X) ,Komunikasi (Y) berpengaruh terhadao kinerja pegawai senilai 0.874 sisanya $15 \%$ dipengaruhi variable lain seperti kerjasama tim, komitmen organisasi dan dan faktor lainnya yang tidak di bahas dalam penelitian ini

\section{Pengaruh Karakter Individu Terhadap Kinerja}

Uji-t adalah jenis pengujian statistika untuk mengetahui apakah ada perbedaan dari nilai yang diperkirakan dengan nilai hasil perhitungan statistika.Uji t pada dasarnya menunjukkan seberapa jauh pengaruh variabel bebas secara individual dalam menerangkan variasi variabel terikat. 


\section{Tabel 5}

Tabel Uji t

\begin{tabular}{llrr}
\hline \multicolumn{1}{c}{ Model } & \multicolumn{1}{c}{$\mathrm{t}$} & \multicolumn{1}{c}{ Sig. } \\
\hline 1 & (Constant) & 1.454 & .149 \\
& Karakter_Individu( & 17.278 & .000 \\
X) & & \\
\hline
\end{tabular}

Sumber : Data diolah ( 2019)

Dari hasil analisis di atas diperoleh nilai signifikasi karakter individu sebesar $0.000<0.05, \mathrm{t}_{\text {hitung }}>\mathrm{t}_{\text {tabel }} 17.278>1.989$, sehingga dapat disimpulkan bahwa secara langsung terdapat pengaruh signifikasi karakter individu terhadap komunikasi.Hal ini sejalan penelitian Ratna Handayati (2016) bahwa Karakteristik individu berpengaruh positif dan signifikan terhadap kinerja karyawan

\section{Pengaruh Karakter Individu dan Komunikasi terhadap Kinerja}

Uji F dikenal dengan Uji serentak atau uji Model/Uji Anova, yaitu uji untuk melihat bagaimanakah pengaruh semua variabel bebasnya secara bersama-sama terhadap variabel terikatnya. Atau untuk menguji apakah model regresi yang kita buat baik/signifikan atau tidak baik/non signifikan

\section{Tabel 6}

ANOVA ${ }^{b}$

\begin{tabular}{llccccc}
\hline \multicolumn{1}{c}{ Model } & $\begin{array}{c}\text { Sum of } \\
\text { Squares }\end{array}$ & Df & $\begin{array}{c}\text { Mean } \\
\text { Square }\end{array}$ & F & Sig. \\
\hline 1 Regression & 3945.354 & 2 & 1972.67 & 257.569 & $.000^{\mathrm{b}}$ \\
& & & 7 & & \\
& Residual & 712.271 & 93 & 7.659 & & \\
$\quad$ Total & 4657.625 & 95 & & & \\
\hline
\end{tabular}

a. Dependent Variable: Kinerja(Y)

b. Predictors: (Constant), Komunikasi (Z), Karakter_Individu(X)

Sumber : Data diolah ( 2019)

Dari hasil analisis diatas diperoleh nilai signifikasi sebesar $0.000<0.05$, diketahui $\mathrm{F}_{\text {hitung }}>\mathrm{F}_{\text {tabel }}, 257.569>3.09$ maka sebagaimana dasar pengambilan keputusan dalam uji $\mathrm{F}$ bahwa hipotesis diterima .

\section{Pengaruh Karakter Individu melalui Komunikasi terhadap Kinerja}

Selanjutnya dari hasil ouput SPSS menunjukan bahwa nilai dari standardized beta yang diperoleh dengan persaman regresi sederhana Karakter Individu (X) terhadap Komunikasi (Y) Hasil Standardized Coefficients Beta Karakter Individu pada persamaan 1 sebesar 0.872 dan signifikasi pada 0.000 yang berarti Karakter Individu mempengaruhi Komunikasi (Y). Nilai koefisien standardized beta 0.872 merupakan nilai path atau jalur p2. Hasil dari output pada persamaan regresi 2 dengan metode berganda nilai yang dihasilkankan standardized beta untuk Karakter Individu (X) sebesar 0.361 dan standardized beta Komunikasi (Y) sebesar 0.588 semuanya signifikan.Nilai dari standardized beta untuk Karakter Individu 0.361 merupakan jalur p1 dan 
nilai standardized beta Komunikasi (Z) 0.588 merupakan jalur p3. Untuk besarnya nilai e1 $=\sqrt{(1-0.761)}=0,488$ dan besar nya e2 $=\sqrt{(1-0.874)}=0.354$ Hasilnya dapat dilihat pada gambar dibawah ini

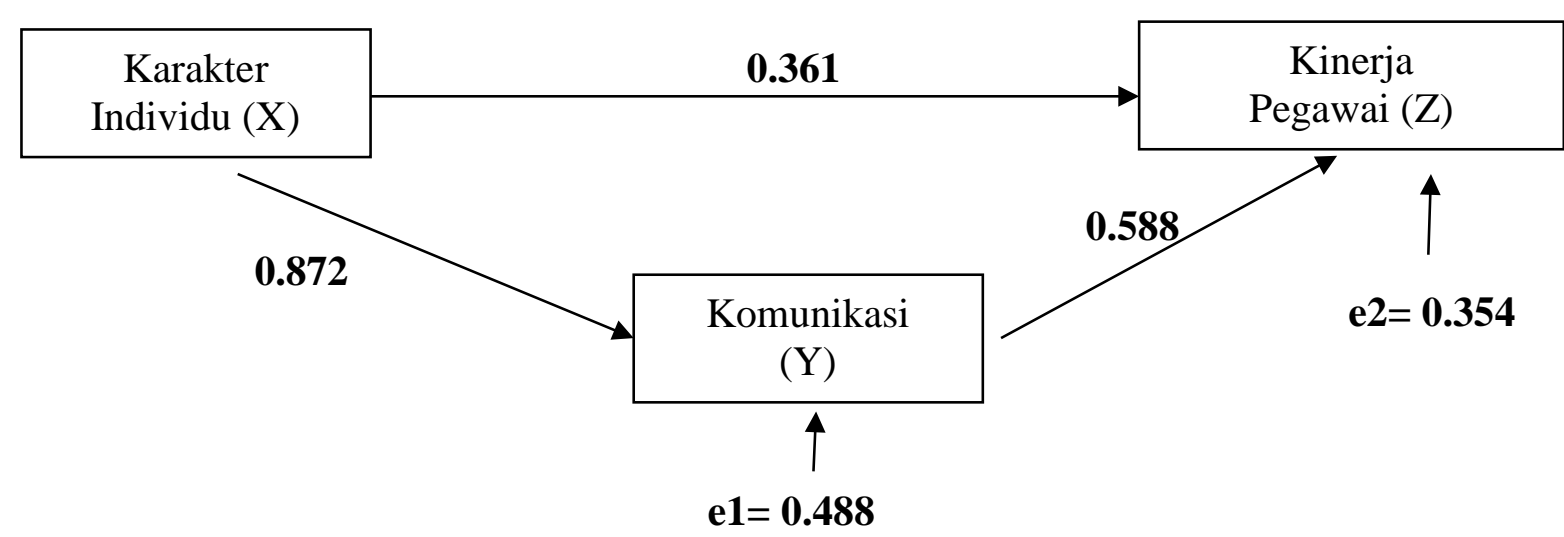

Gambar 2

Gambar Hasil Analisis Jalur Intevening

Berdasarkan hasil analisis jalur menunjukan bahwa Karakter Individu dapat berpengaruh langsung ke Kinerja Pegawai dan dapat juga berpengaruh tidak langsung yaitu dari Karakter Individu ke Komunikasi (sebagai intervening) lalu menuju Kinerja Pegawai. Nilai besarnya pengaruh langsung adalah 0.361 , sedangkan besarnya pengaruh tidak langsung yaitu dengan menggunakan metode perhitungan $(0.872 \mathrm{X} 0.588)=0,512$ atau total pengaruh Karakter Individu kepada Kinerja Pegawai $=0.361+(0.872$ X 0.588 $)=0.873$ ini berarti besarnya pengaruh tidak langsung lebih besar dibandingkan pengaruh langsung ,hasil ini menunjukan bahwa secara tidak langsung karkter individu melalui komunikasi mempunyai pengaruh signifikan terhadap kinerja.

\section{PENUTUP}

Hasil hipotesa diperoleh terdapat pengaruh signifikasi karakter individu terhadap komunikasi. Hipotesa Uji $\mathrm{F}$ diperoleh hasil analisis diatas sebagaimana dasar pengambilan keputusan dalam uji $\mathrm{F}$ bahwa hipotesis diterima. Untuk hasil analisis jalur intervening menunjukan bahwa karakter individu dapat berpengaruh langsung ke kinerja pegawai dan dapat juga berpengaruh tidak langsung yaitu dari karakter individu ke komunikasi ( sebagai intervening) lalu menuju kinerja pegawai. Hasil analisa diatas menunjukan bahwa secara tidak langsung karakter individu melalui komunikasi mempunyai pengaruh signifikan terhadap kinerja.

Hasil Persamaan1 dengan Regresi Sederhana bahwa terdapat pengaruh positif karakter individu (X) terhadap komunikasi (Z). Selanjutnya persamaan 2 dengan regresi tersebut terdapat pengaruh positif Karakter Individu (X) terhadap kinerja dan komunikasi (Y) sebagai variabel intervening berpengaruh dan positif terhadap kinerja pegawai (Z)

Untuk meningkatkan kinerja pegawai pada UPT SDA Bah Bolon, Dinas Sumber Daya Air, Cipta Karya, dan Tata Ruang Provinsi Sumatera Utara Jl. Asahan Km. 3,5 Pematangsiantar diharapkan agar pegawai lebih memperhatikan semua faktor yang sudah diatur dalam PP No. 46 Tahun 2011 
(Pasal 1 ayat 2) tentang penilain kinerja pegawai dimana berisi tanggung jawab, kualitas hasil kerja, ketelitian hasil kerja dan menaati peraturan guna mencapai tujuan bersama

\section{REFERENSI}

Arikunto, Suharsimi. 2013. Prosedur Penelitian: Suatu Pendekatan Praktik. Jakarta: Rineka Cipata

Ardiansyah, Dimas Okta ( 2016), Pengaruh Komunikasi Terhadap Kinerja Karyawan Dengan Dimediasi Oleh Kepuasan Kerja (Studi Pada Bagian Produksi Pabrik Kertas PT. Setia Kawan Makmur Sejahtera Tulungagung). Jurnal E Jurnal Bisnis dan Manajemen, Vol 3, No 1 (2016) Febriansyah ,Pradana Ajie, 2015. Pengaruh Komunikasi Terhadap Kinerja Pegawai Negeri Sipil (Studi Pada Dinas Kesehatan Kota Malang): Jurnal E Jurnal Administrasi Publik, Vol 3 Nomor 2

Gaffar, Indar Dewi. 2017. Pengaruh Karakteristik Individu Terhadap Kinerja Karyawan Pada PT Sumber Alfaria Trijaya di Makassar, Jurnal Riset Edisi XVI, Unibos Makasar Mei 2017

Ghozali, Imam. 2012. Aplikasi Analisis Multivariate dengan Program IBM SPSS. Yogyakarta: Universitas Diponegoro.

Jacobis , Ghiok Vanali, Christoffel Kojo dan Rudy S Wenas, 2015. Pengaruh Karakteristik Individu dan Lingkungan Kerja Terhadap Kinerja Pegawai di Dinas Lingkungan Hidup Daerah Provinsi Sulawesi Utara, Jurnal EMBA Vol.5 No24 Juni 2017

Hurriyati, Ratih, 2010. Bauran Pemasaran dan Loyalitas Konsumen. Bandung: ALFABETHA.

Handayati Ratna ,2016, Pengaruh Karakteristik Individu Terhadap Kinerja Karyawan Di Bank Jatim Cabang Lamongan ( Suatu Studi Pada Bank Jatim Cabang Lamongan) : E Jurnal Volume I No. 2, Juni 2016.

Mariani ,Luh Mang Indah dan Ni Ketut Sariyathi.2017 . Pengaruh Motivasi, Komunikasi Dan Disiplin Kerja Terhadap Kinerja Karyawan Warung Mina Peguyangan Di Denpasar, E-Jurnal Manajemen Unud, Vol. 6, No. 7, 2017: 3540-3569

Mangkunegara, Prabu. 2017. Manajemen Sumber Daya Manusia Perusahaan. Cetakan Keduabelas. Bandung: PT Remaja Rosdakarya

Robbins, Stephen P.dan Mary Coulter, 2010. Manajemen. Edisi Kesepuluh. Jakarta: Erlangga

Rahman Abdul. 2013.Pengaruh Karakteristik Individu, Motivasi Dan Budaya Kerja Terhadap Kinerja Pegawai Pada Badan Keluarga Berencana Dan Pemberdayaan Perempuan Kabupaten Donggala : Jurnal E-Jurnal Katalogis, Volume I Nomor 2

Sule dan Kurniawan. 2009. Pengantar Manajemen. Edisi Pertama. Cetakan Keempat. Jakarta: Kencana.

Sugiyono. 2016. Metode Penelitian Kuantitatif Kualitataif dan Kombinasi (Mixed Methods). Bandung: Alfabeta.

Setyowati Trias, 2016, Analisis Karakteristik Individual, Kompetensi Dan Komunikasi Pengaruhnya Terhadap Kinerja Karyawan ( Studi Pada 
Perusahaan PT. Mangli Djaya Raya Jember ) Jurnal Manajemen Dan Bisnis Indonesia Vol 2. No. 2 Desember 2016.

Peraturan Pemerintah Nomor 46 Tahun 2011 tentang Penilaian Prestasi Kerja Pegawai Negeri Sipil.

Purwanto, Djoko. 2011. Komunikasi Bisnis. Jakarta: Erlangga

Wirawan, 2014, Kepemimpinan, Teori, Psikologi, Perilaku Organisasi, Aplikasi dan Penelitian:Contoh Aplikasi untuk Kepemimpinan Wanita, Organisasi Bisnis, Pendidikan dan Militer, Rajagrafindo Persada, Jakarta 